\title{
KONSTRUKSI KREATIF PEMEROLEHAN KOMPETENSI PRAGMATIK ANAK USIA PRASEKOLAH
}

\author{
oleh Dyah Werdiningsih \\ FKIP Universitas Islam Malang
}

\begin{abstract}
This article is about a research conducted with the objective of studying the process of creative construction, which consists of a process of hypothesis formulation and that of hypothesis testing, in Javanese-Indonesian bilingual preschool children's acquisition of pragmatic competence in using Indonesian. Employing a longitudinal research design, the research used subjects of different ages: preschool children 2, 3, 4, and 5 years of age. The data were compiled by means of observations together with data recording by using electronic recording equipment and field-note data cards. The data were analyzed by using a technique of performance analysis. On the basis of the data analysis, it has been found that the creative construction in the acquisition of pragmatic competence has been seen in preschool-age children's use of learning strategies, which consist of two types: cognitive and social strategies.
\end{abstract}

Keywords: creative construction, pragmatic competence, child learners

\section{A. PENDAHULUAN}

Pemerolehan bahasa anak merupakan suatu proses yang terjadi dalam struktur mental secara bertahap. Setiap anak mampu memahami dan memproduksi tuturan setelah terjadi proses internalisasi dalam struktur mental mereka. Proses ini dapat terjadi karena sejak lahir manusia dilengkapi dengan perangkat bawaan dalam bentuk mekanisme abstrak yang lazim disebut Language Acquisition Device (LAD). LAD merupakan perangkat pemerolehan bahasa yang bersifat kodrati. Dengan perangkat ini pemerolehan bahasa anak dapat terjadi seiring dengan perkembangan psikologisnya. Lingkungan berperan penting untuk memberikan data berupa masukan bahasa. Proses pemerolehan bahasa dipengaruhi oleh faktor lingkungan, tetapi esensi dari proses pemerolehan itu sendiri merupakan inner directed. Dengan demikian, pemerolehan bahasa terjadi karena adanya faktor bawaan dan faktor lingkungan yang memberikan masukan pada anak.
Pandangan bahwa pemerolehan bahasa dipengaruhi oleh faktor LAD dan lingkungan bahasa dikenal dengan pandangan interaksionisme. Pandangan ini kemudian digunakan sebagai kerangka acuan dalam penelitian ini. Berdasarkan pandangan ini proses pemerolehan bahasa terjadi karena adanya peran faktor psikologis dan faktor sosial. Keberadaannya mekanisme bawaan memungkinkan seseorang mempelajari bahasa. Akan tetapi, seseorang tidak dapat memperoleh bahasa tanpa adanya pajanan.

Peran faktor psikologis dan sosial pada pemerolehan bahasa anak tampak sejak awal pemerolehan bahasanya. Pada masa prabahasa anak telah memperoleh pajanan abstraksi bahasa sebagai simbol komunikasi. Pajananpajanan yang diperoleh itu diproses dalam LAD menjadi perangkat sistem bahasa. Perangkat sistem bahasa yang ada dalam otak anak ini akan muncul dan dapat diketahui oleh orang lain ketika anak mulai bisa mengucapkan satu suku kata atau kata sebagai suatu kalimat. Jika 
sudah memiliki kemampuan untuk mengucapkan suku kata atau kata, anak sudah menguasai kata sebagai simbol dan konsepsi maknanya untuk menyatakan suatu maksud. Proses penguasaan yang terjadi pada anak tersebut merupakan proses yang melibatkan perangkat bawaan dalam struktur mentalnya dan proses pengalaman berbahasa yang dialaminya dalam praktik berkomunikasi di lingkungannya. Proses interaktif antara kemampuan bawaan dan pengalaman berbahasa ini menyebabkan proses pemerolehan bahasa anak berlangsung secara terus-menerus hingga mereka dewasa.

Untuk dapat menguasai bahasa tertentu sebagai alat untuk berkomunikasi dengan orang lain, anak mengalami proses pemerolehan bahasa dengan memasukkan pajanan bahasa dari lingkungan ke dalam struktur mentalnya. Sebagai contoh, anak memperoleh kompetensi pragmatik apabila telah memasukkan aspekaspek kompetensi pragmatik itu dalam struktur mentalnya. Pemerolehan kompetensi pragmatik anak ditandai dengan adanya pemahaman dan pemroduksian bentuk-bentuk tuturan tertentu yang digunakan untuk menyatakan maksud sesuai dengan konteks penggunaannya dalam konstruksi tertentu.

Bahasa adalah sistem bunyi yang digunakan dalam komunikasi interpersonal oleh sekelompok manusia untuk mengungkapkan suatu peristiwa dan proses yang terdapat di lingkungan sekitarnya (Carrol dalam Suparno, 1996:2). Ketidakmampuan dan ketidaktepatan anak dalam memahami tuturan yang dikemukakan orang lain dan memproduksi tuturan untuk menyatakan maksud kepada orang lain menjadi hambatan baginya dalam bersosialisasi dengan orang lain. Untuk dapat menyatakan maksud secara tepat ini dibutuhkan perangkat kemampuan tertentu, antara lain memilih kosakata yang tepat, menyusun struktur kalimat yang bermakna, dan menganalisis konteks tuturan yang sesuai dengan peristiwa tutur yang sedang berlangsung. Kemampuan menggunakan bahasa sesuai dengan konteks ini merupakan kompetensi pragmatik. Proses pemerolehan kompetensi pragmatik dalam struktur mental anak tersebut dapat dicapai dengan menggunakan strategi tertentu.

Dalam proses pemerolehan kompetensi pragmatik terdapat faktor penting yang perlu diperhatikan, yaitu usaha anak untuk memperoleh bentuk-bentuk tuturan yang berterima untuk menyatakan maksud dan mengkomunikasikannya ketika berinteraksi dengan mitra tutur. Dalam berkomunikasi dengan bahasa yang sedang dipelajari, seseorang berusaha menggunakan berbagai strategi untuk menguasai bentuk-bentuk tuturan yang diperlukan untuk menyatakan maksud dan mencapai keberhasilan tujuan komunikasi yang diinginkan. Lebih lanjut, menegaskan bahwa dalam penggunaan strategi pemerolehan bahasa terdapat tiga proses mental yang terjadi pada pembelajar, yaitu proses bagaimana pembelajar memperoleh masukan bahasa dan menginternalisasikannya, memproduksikannya, serta mengkomunikasikannya. Ketiga proses tersebut disebut sebagai strategi belajar, strategi produksi, dan strategi komunikasi.

Sejalan dengan tujuan penelitian ini, strategi pemerolehan yang dikaji lebih lanjut adalah strategi belajar pembelajar anak. Hal ini didasarkan pada pertimbangan bahwa penggunaan strategi ini berperan penting dalam mendukung proses penguasaan bentuk-bentuk tuturan tertentu dan pemerolehan masukan bahasa yang lebih banyak dan bermakna untuk meningkatkan kemampuan berbahasanya.

Strategi belajar digunakan anak terwujud dalam berbagai jenis. Penggunaan strategi belajar anak ini tampak pada tindakantindakan atau perilaku-perilaku khusus yang dilakukan anak untuk meningkatkan kemampuan bahasanya, misalnya dengan cara meniru, mengulang-ulang, mentransfer ke dalam bahasa lain, memperbaiki tuturan, meminta klarifikasi, dan lain-lain. Sebagai contoh, anak melakukan pengulanganpengulangan karena ada sesuatu yang harus diingat bagaimana penggunaannya. Tindakantindakan ini terjadi secara alami dan dapat diamati dalam perilaku berbahasa anak pada 
saat berinteraksi dengan mitra tuturnya. Perilaku tersebut dipengaruhi oleh beberapa karakteristik umum, seperti perkembangan usia, kemampuan bahasa, dan kondisi psikologis pembelajar bahasa.

Sebagai penutur yang belum menguasai bahasa secara sempurna, proses pemerolehan kompetensi pragmatik anak-anak didukung oleh penggunaan strategi pemerolehan bahasa tertentu. Berdasarkan pengkategorian kompetensi pragmatik, pemerolehan kompetensi pragmatik anak ini mencakup aspek kompetensi ilokusi dan kompetensi sosiolinguistik. Kompetensi ilokusi tergambar pada kemampuan anak untuk mengemukakan maksud tertentu kepada mitra tuturnya, seperti untuk menjelaskan fakta, menanyakan fakta, menyatakan nasihat, menyatakan terima kasih, menyatakan permohonan, menyatakan maaf, menyatakan penolakan, menyatakan pendapat, dan memberi nasihat. Adapun kompetensi sosiolinguistik tampak pada kepekaan anak menggunakan bentuk-bentuk tuturan yang sesuai dengan konteks. Dengan demikian, strategi pemerolehan kompetensi pragmatik anak tampak pada cara-cara yang digunakan anak untuk menguasai bentuk-bentuk tuturan yang digunakan untuk menyatakan maksud tertentu kepada mitra tuturnya sesuai dengan konteks penggunaannya.

Berdasarkan gagasan tersebut, pemerolehan kompetensi pragmatik anak terealisasi pada tindak tutur dalam komunikasi, yakni terwujud pada kompetensi ilokusi. Kompetensi ilokusi tersebut tampak pada tuturan anak dengan ciri-ciri tertentu. Aspekaspek pragmatik dalam tindak tutur inilah yang merupakan bentuk nyata dari penggunaan bahasa dalam berbagai peristiwa komunikasi. Pengkajian strategi pemerolehan kompetensi pragmatik dalam tindak tutur ini juga didasarkan pada pandangan bahwa unit komunikasi bahasa bukan berupa simbol, kata, atau kalimat, tetapi lebih merupakan pemroduksian simbol, kata, atau kalimat yang terealisasi dalam tindak tutur (Mey, 1993:110; Schiffrin, 1994:54; dan Duranti, 2000:45). Pertimbangan lain tentang perlunya pengkajian strategi pemerolehan kompetensi pragmatik ini adalah adanya fakta bahwa pembelajar anak yang dijadikan subjek penelitian ini telah mempunyai kemampuan untuk memroduksi tuturan secara lengkap.

Pemilihan anak usia prasekolah sebagai subjek penelitian ini didasari bahwa pada usia setelah lima tahun proses perkembangan bahasa anak sudah menyerupai orang dewasa, baik dari segi aspek bunyi, bentuk kata, struktur kalimat, maupun organisasi wacana. Tahap pengembangan kompetensi pragmatik anak terjadi setelah usia anak lebih dari enam tahun ( $>6$ tahun). Penelitian ini menggunakan subjek anak usia prasekolah di bawah usia enam tahun $(<6$ tahun). Hal ini dimaksudkan untuk mengetahui kekhasan strategi pemerolehan kompetensi pragmatik anak sebelum kompetensi berbahasa mereka menyerupai orang dewasa dan masa pengembangan kompetensi pragmatiknya berlangsung.

Anak usia prasekolah yang digunakan sebagai subjek penelitian ini adalah anak usia 2 , 3, 4, dan 5, tahun dwibahasawan JawaIndonesia. Penggunaan bahasa dalam komunikasi, baik bahasa Indonesia (BI) maupun bahasa Jawa (BJ) oleh anak usia prasekolah merupakan fakta adanya fenomena penguasaan BI dan BJ pada anak usia prasekolah. Adanya penggunaan bahasa secara konsisten oleh anak-anak tersebut menunjukkan adanya fenomena penguasaan dua bahasa yang diperoleh secara simultan. Hal ini terjadi karena sejak awal pemerolehan bahasa anak telah menggunakan dua bahasa tersebut dalam berinteraksi sehari-hari. Dengan kata lain, sejak dini anak telah menjadi dwibahasawan karena lingkungan sosialnya mengkondisikan mereka untuk menguasai kaidah-kaidah penggunaan BI dan BJ dalam percakapan sehari-hari. Apabila anak memperoleh dua bahasa sebelum usia 3 tahun, anak itu dianggap memperoleh bahasa secara simultan. Dengan demikian, pada penelitian ini dikaji proses pemerolehan BI sebagai bahasa pertama (B1) yang diperoleh anak secara simultan dengan BJ. 
Proses penguasaan terhadap dua bahasa atau lebih oleh anak tidak terlepas dengan latar belakang budaya yang mewadahi kedua bahasa tersebut. Tata cara berkomunikasi tidak terlepas dari kerangka sosial budaya tertentu. Dengan demikian, pada proses pemerolehan bahasa anak dwibahasawan JawaIndonesia secara bersamaan mereka menguasai dua budaya yang melatari kedua bahasa tersebut. Mereka akan mempelajari norma sosial kedua bahasa tersebut. Penguasaan terhadap norma sosial bahasa ditunjukkan melalui perilaku berbahasa anak yang berterima bagi masyarakat sekitarnya. Pada proses pemerolehan bahasanya, BJ dipelajari dengan kaidah penggunaan yang diatur berdasarkan adat-istiadat dan tata nilai budaya yang dianut oleh masyarakat Jawa. Bersamaan dengan itu anak dituntut untuk menggunakan kaidah-kaidah yang berlaku dalam BI sesuai dengan konteks penggunaannya. Kemampuan anak menggunakan kaidah-kaidah BJ dan BI tersebut mencerminkan kemampuan anak dalam menggunakan norma-norma dan sikap mereka terhadap tata nilai budaya yang melatari kedua bahasa tersebut.

Penelitian ini difokuskan pada pengkajian tentang bagaimana konstruksi kreatif pemerolehan kompetensi pragmatik berbahasa Indonesia (BI) anak usia prasekolah dwibahasawan Jawa-Indonesia. Konstruksi kreatif merupakan proses pembentukan secara bertahap berdasarkan ujaran yang didengar oleh anak sebagai usaha membentuk berbagai macam hipotesis tentang sistem kaidah bahasa yang dipelajarinya. Pembentukan itu berlangsung dengan dikendalikan oleh suatu mekanisme kejiwaan yang bersifat bawaan atau kodrati dan terepresentasi dalam strategi pemerolehan bahasa yang digunakan anak. Secara khusus, dalam penelitian ini dikaji tentang bagaimanakah proses konstruksi kreatif yang terepresentasi dalam strategi pemerolehan kompetensi pragmatik ber-BI yang digunakan anak usia prasekolah dwibahasawan JawaIndonesia, yang meliputi (a) strategi kognitif dalam pemerolehan pragmatik anak usia prasekolah dwibahasawan Jawa-Indonesia? dan (b) strategi sosial dalam pemerolehan pragmatik anak usia prasekolah dwibahasawan Jawa-Indonesia?

\section{B. METODE PENELITIAN}

Berdasarkan waktu yang digunakan untuk mengamati subjek, penelitian ini menggunakan desain/rancangan bujur (longitudinal). Dengan cara ini peneliti tidak mengikuti subjek dalam waktu yang lama dalam periode tertentu, tetapi mengamati tahap tertentu pada proses pemerolehan bahasa subjek dalam waktu tertentu. Dalam hal ini peneliti mengamati pemerolehan kompetensi pragmatik subjek dengan usia beda, yaitu anak usia prasekolah dwibahasawan Jawa-Indonesia usia 2, 3, 4, dan 5 tahun pada suatu tahap tertentu.

Untuk mencapai tujuan penelitian, dalam penelitian ini digunakan pendekatan kualitatif. Ancangan teori yang digunakan dalam penelitian ini adalah teori pragmatik dan teori pemerolehan bahasa, khususnya teori konstruksi kreatif. Teori pragmatik dimanfaatkan untuk memahami aspek-aspek pragmatik yang digunakan anak dalam kegiatan komunikasi yang merupakan realiasi dari kompetensi pragmatiknya. Teori pemerolehan bahasa dimanfaatkan untuk mengkaji, melacak, dan menemukan strategi pemerolehan pragmatik BI anak, yaitu langkah-langkah atau cara yang dilakukan anak dalam mengkonstruksi secara kreatif kompetensi pragmatik ber-BI anak usia prasekolah dwibahasawan Jawa-Indonesia.

Data penelitian ini terdiri atas tuturan anak usia prasekolah dwibahasawan JawaIndonesia yang diujarkan dalam interaksi dengan berbagai mitra tutur, dan catatan lapangan tentang konteks komunikasi yang diperoleh dari hasil pengamatan peneliti di lapangan. Subjek penelitian ini adalah penutur bahasa anak usia prasekolah dwibahasawan Jawa-Indonesia, yakni delapan anak usia prasekolah, yang terdiri atas anak usia 2, 3, 4 dan 5 tahun masing-masing dua orang. Penetapan subjek penelitian ini didasarkan pada asas kecukupan data yang diperlukan 
dalam penelitian ini. Penentuan subjek ini dilakukan dengan alasan bahwa dengan delapan subjek tersebut diprediksi telah diperoleh data yang cukup memadahi untuk menjawab permasalahan penelitian ini. Namun, jika ternyata perolehan data belum memenuhi target sebagaimana yang diharapkan maka dilakukan penambahan subjek hingga memenuhi kecukupan data.

Dalam penelitian ini peneliti berlaku sebagai instrumen kunci. Data dalam penelitian ini berupa perilaku manusia yang hanya dapat dipahami melalui interaksi antara peneliti dengan subjek dan faktor-faktor yang berperan dalam kegiatan berkomunikasi subjek. Instrumen tambahan yang digunakan adalah pedoman pengamatan dan alat bantu pengamatan, yaitu perekam elektronik (tape recorder) serta alat pencatatan lapangan. Pedoman pengamatan dalam penelitian ini disusun sebagai rambu-rambu mengenai apa yang harus diamati dalam melakukan pengamatan lapangan. Pedoman pengamatan disusun untuk mengumpulkan data dalam bentuk tuturan verbal yang diujarkan subjek beserta konteks tuturan yang menyertai dalam interaksi anak dwibahasawan Jawa-Indonesia dengan mitra tuturnya. Dalam kegiatan pengamatan lapangan dilakukan perekaman data, yaitu tuturan anak dengan berbagai mitra tutur. Perekaman data dilakukan dengan menggunakan alat perekam elektronik (tape recorder), baik dilakukan secara sembunyisembunyi maupun sepengetahuan subjek. Hal ini dilakukan untuk menjaga kealamiahan data yang diperoleh dari semua subjek. Selama kegiatan pengamatan berlangsung dilakukan pencatatan data lapangan. Pencatatan data lapangan diperlukan untuk mengetahui konteks tuturan yang meliputi (1) latar tempat, latar waktu, dan latar penuturan, yaitu keadaan psikologis penutur pada saat santai, serius, atau emosional, serta situasi tutur saat berlangsungnya komunikasi, (2) status dan peran penutur dan mitratutur, dan (3) topik tuturan ketika interaksi sedang berlangsung.

Teknik pengumpulan data yang digunakan adalah teknik pengamatan. Teknik pengamatan dilakukan baik dengan partisipasi maupun nonpartisipasi. Pengamatan difokuskan pada kegiatan anak usia prasekolah dwibahasawan Jawa-Indonesia dalam melakukan interaksi verbal dengan berbagai mitra tutur. Teknik pengamatan dilengkapi dengan pencatatan lapangan dan perekaman.

Untuk mencapai tujuan penelitian ini, berbagai data pendukung penelitian ini dianalisis berdasarkan teknik analisis performansi. Teknik analisis ini didasarkan pada gagasan yang mengemukakan bahwa tipe analisis data dalam penelitian pemerolehan bahasa meliputi analisis kontrastif, analisis kesalahan, analisis performansi, dan analisis wacana. Analisis performansi ini telah banyak digunakan para pakar dalam penelitian strategi belajar anak pada awal pemerolehan bahasanya dan penelitian tentang pemerolehan bentuk dan fungsi penggunaan tuturan sehingga relevan digunakan dalam penelitian ini.

\section{HA S I L P ENELITIAN DAN PEMBAHASAN}

Berdasarkan hasil analisis ditemukan penggunaan strategi belajar anak usia prasekolah memiliki karakteristik yang tampak pada tipe dan variasi tipe, faktor penyebab, dan fungsi penggunaannya dalam pemerolehan kompetensi pragmatik. Strategi belajar anak usia prasekolah dapat dikelompokkan dalam dua kategori, yaitu strategi kognitif dan strategi sosial. Yang tergolong strategi kognitif adalah peniruan tuturan, pengulangan tuturan, dan perbaikan. Adapun yang tergolong ke dalam strategi sosial adalah permintaan klarifikasi dan pertanyaan responsi-timbal balik.

Tipe-tipe strategi belajar tersebut terealisasi dalam berbagai tipe dan variasi tipe yang memiliki ciri-ciri berbeda dengan strategi belajar yang digunakan oleh pembelajar yang belajar secara formal di sekolah. Pada pembelajar yang telah belajar di sekolah ini strategi belajar diorientasikan pada upayaupaya yang dilakukan untuk meningkatkan kemampuan berbahasa setelah mereka mengikuti proses pembelajaran. Kajian strategi belajar dan penggunaannya pada pembelajar 
usia sekolah telah banyak dilakukan oleh para pakar, seperti Ellis (1995). Adapun penggunaan strategi belajar pada pembelajar anak-anak belum banyak disinggung. Dengan demikian, temuan penelitian ini bermanfaat untuk memberikan gambaran mengenai penggunaan strategi belajar anak yang berupa deskripsi dan eksplanasi tentang karakteristik (1) tipe dan variasi tipe, (2) faktor penyebab, dan (3) fungsi penggunaan strategi belajar anak usia prasekolah.

Karakteristik penggunaan tipe dan variasi tipe strategi belajar anak usia prasekolah ditandai dengan adanya tiga ciri, yakni digunakan dalam lingkungan informal, digunakan dalam praktik berkomunikasi secara alami, dan dilakukan tanpa adanya unsur kesengajaan untuk menguasai bentuk-bentuk tuturan tertentu. Berdasarkan ketiga hal tersebut, penerapan strategi belajar pada anak usia prasekolah memperlihatkan adanya keunikan-keunikan. Keunikan ini menunjukkan kekhasan strategi belajar anak usia prasekolah dibandingkan dengan strategi belajar anak usia sekolah yang dilakukan dalam lingkungan pembelajaran formal dan dilakukan secara sadar untuk menguasai bentuk-bentuk tuturan tertentu. Kekhasan tersebut tampak pada penggunaan tipe dan variasi tipe strategi belajar dalam pemerolehan kompetensi pragmatik.

Pertama, peniruan tuturan dilakukan dalam dua variasi tipe, yaitu peniruan tuturan karena kesulitan penuturan dan karena kesalahan penuturan. Perilaku anak ini dilakukan secara fungsional, yakni untuk memenuhi kebutuhan komunikasi ketika anak tidak dapat menyatakan maksud dan ketika anak melakukan kesalahan dalam menyatakan maksud kepada mitra tuturnya. Peniruan tuturan ini tidak dilakukan secara spontan oleh anak tetapi atas permintaan mitra tuturnya. Hal ini sejalan dengan penjelasan Ninio dan Snow (1996) bahwa anak-anak menirukan tuturan berupa jawaban atas pertanyaan yang tidak mampu mereka jawab dan para orangtua meminta anak-anak untuk meniru bentukbentuk tuturan tertentu yang diujarkannya. Peniruan tuturan anak ini, merupakan bentuk penggunaan tuturan interpersonal yang dilakukan untuk menguasai maksud komunikatif atau pragmatis pada awal tuturan anak.

Kedua, pengulangan tuturan dilakukan anak usia prasekolah dengan cara melakukan pengulangan tuturan sendiri, pengulangan tuturan orang dewasa, dan pengulangan tuturan teman sebaya. Perilaku ini ditandai oleh penggunaan bentuk-bentuk tuturan secara berulang-ulang pada setiap kesempatan berkomunikasi. Dengan cara ini, anak dapat menguji hipotesis tentang penguasaannya terhadap bentuk-bentuk tuturan tertentu. Dari penggunaan tuturan secara berulang-ulang dalam praktik komunikasi, anak dapat mengetahui ketepatan atau ketidaktepatan bentuk tuturan yang digunakannya hingga pada akhirnya dapat menggunakannya secara otomatis.

Ketiga, perbaikan tuturan dilakukan anak dalam dua cara, yaitu perbaikan tuturan sendiri dan perbaikan tuturan berdasarkan respon mitra tutur. Strategi ini digunakan karena kesadaran anak akan kesalahan dalam tuturan yang diujarkannya. Kesadaran tersebut diperoleh anak berdasarkan pemahaman anak sendiri atau berdasarkan respons mitra tutur. Pemahaman anak sendiri terhadap kesalahan dalam tuturannya diperoleh berdasarkan pengetahuan dan pengalaman berbahasanya serta kemampuannya untuk melakukan pemonitoran diri selama melakukan aktivitas berkomunikasi dan adanya respons negatif dalam bentuk koreksi dari mitra tuturnya. Selain itu, anak usia prasekolah tidak jarang meminta mitra tuturnya untuk memperbaiki tuturan yang diproduksinya.

Keempat, permintaan klarifikasi dilakukan dengan cara meminta mitra tutur untuk menuturan kembali dan penjelasan maksud bentuk-bentuk tuturan yang tidak dipahaminya. Kecakapan dalam mengajukan permintaan klarifikasi ini dimiliki anak berdasarkan pajanan bentuk-bentuk pertanyaan klarifikasi dan pertanyaan untuk merevisi tuturan yang diperoleh dalam lingkungan berbahasa dalam praktik berkomunikasi yang 
terjadi secara alami. Anak mengajukan permintaan klarifikasi sebagaimana yang dilakukan orangtua, kakak, dan penutur lain di sekitarnya ketika melakukan perilaku serupa baik kepadanya maupun kepada penutur lain.

Kelima, pertanyaan responsi-timbal balik digunakan anak usia prasekolah pada usia 5 tahun. Tipe strategi ini digunakan dengan cara bekerja sama dengan penutur yang dianggap telah menguasai BI dengan baik. Anak melakukan aktivitas tersebut didorong oleh keinginannya untuk berinteraksi dan untuk menjalin kedekatan sosial dengan mitra tuturnya. Pada anak usia prasekolah tipe strategi ini dilakukan dalam bentuk tanyajawab secara bergantian dengan mitra tuturnya. Dengan menanyakan hal-hal yang ingin diketahuinya anak dapat mempelajari bentukbentuk tuturan untuk menyatakan pertanyaan. Sebaliknya, dengan menjawab pertanyaan dapat belajar menyatakan jawaban atas pertanyaan yang diajukan kepadanya.

Penggunaan strategi belajar dalam proses pemerolehan kompetensi pragmatik anak usia prasekolah disebabkan oleh berbagai faktor penyebab, yaitu perkembangan usia, tingkat penguasaan bahasa, kedwibahasaan, kepribadian, dan intensitas masukan dan interaksi. Pengaruh perkembangan usia anak terhadap penggunaan strategi belajar dalam pemerolehan kompetensi pragmatik ditunjukkan dengan perbedaan strategi belajar yang digunakan anak pada setiap jenjang usia. Semakin tinggi usia anak, strategi belajar yang digunakan semakin banyak dan bervariasi. Dengan demikian temuan penelitian ini mendukung temuan bahwa perkembangan usia berpengaruh terhadap proses pemerolehan bahasa. Temuan penelitian ini sekaligus membuktikan bahwa efek usia terhadap pemerolehan bahasa tidak terbatas pada proses pemerolehan fonem, morfem, dan kalimat.

Tingkat penguasaan bahasa anak berperan penting dalam pemilihan dan penggunaan tipe dan variasi tipe strategi belajar. Salah satu aspek yang mendukung tingkat penguasaan bahasa anak adalah lama waktu belajar bahasa. Menurut Ellis (1995) lama waktu belajar bahasa dapat mendukung tingkat penguasaan bahasa, terutama pada keberhasilan dalam menguasai kompetensi komunikasi. Lama waktu belajar bahasa anak ditentukan oleh waktu mulainya belajar bahasa. Melalui saluran intrauterine anak telah terekspos bahasa manusia sejak dia masih janin. Pada anak usia prasekolah lama waktu belajar bahasa diketahui berdasarkan perbedaan waktu mulainya belajar bahasa, yakni sesuai dengan usia anak. Dari temuan penelitian ini diperoleh gambaran bahwa tingkat penguasaan bahasa yang berbeda mengakibatkan adanya perbedaan karakteristik tipe dan variasi tipe strategi belajar yang digunakan anak pada tiap jenjang usia, meskipun terdapat beberapa persamaan. Fakta ini menggambarkan adanya perkembangan strategi pemerolehan anak usia prasekolah seiring dengan tingkat penguasaan bahasanya, khususnya kompetensi pragmatik.

Dari penelitian ini ditemukan bahwa perkembangan kompetensi pragmatiknya, anak usia prasekolah sesuai dengan tahapan perkembangan bahasa anak. Tahap perkembangan bahasa anak mencakup enam tahap, yaitu (1) tahap meraban pertama (pralinguistik), (2) tahap meraban kedua (kata nonsens), (3) tahap linguistik I: kalimat satu kata, (4) tahap linguistik II: kalimat dua kata, (5) tahap linguistik III: perkem-bangan tatabahasa, (6) tahap linguistik IV: tahap pradewasa, dan (7) tahap linguistik V: kompetensi penuh. Kesesuaian perkembangan kompetensi pragmatik anak usia prasekolah dengan tahapan perkembangan bahasa anak tampak pada penggunaan tuturan untuk menyatakan berbagai maksud kepada mitra tutur. Sebagai contoh, anak usia 2 tahun menyatakan fakta dalam bentuk tuturan satu kata, yaitu (1) dokter untuk menyatakan Haekal akan pergi ke dokter, (2) Uti untuk menyatakan kata Mbah Putri sakit, dan (3) kepala untuk menyatakan Mbah Putri sakit kepala. Tuturan tersebut menunjukkan bahwa anak usia 2 tahun menggunakan kalimat satu kata. Hal ini sejalan dengan tahapan perkembangan bahasa anak usia 2 tahun, yaitu anak berada pada tahapan Linguistik I (kalimat satu kata). Dengan tuturan 
dalam kalimat satu kata tersebut anak dapat menyatakan berbagai maksud kepada mitra tuturnya. Tuturan anak yang dikemukakan dalam kalimat satu kata dapat mempunyai arti lebih dari satu kata karena kata itu merupakan ekspresi dari ide-ide yang kompleks, yang pada orang dewasa dinyatakan dalam kalimat yang lengkap.

Faktor kedwibahasaan pembelajar berperan penting dalam penggunaan strategi belajar anak usia prasekolah. Hal ini terbukti pada penggunaan strategi belajar yang didasarkan pada bahasa lain, yaitu BJ. Keterkaitan faktor kedwibahasaan anak dengan strategi belajar ditunjukkan dengan penggunaan strategi penerjemahan, baik penerjemahan kata/frase BJ ke dalam BI maupun penerjemahan kalimat BJ ke dalam BI. Dengan cara tersebut anak dapat memanfaatkan BJ sebagai landasan untuk memahami atau menghasilkan tuturan kreatif yang berbeda dengan kaidah yang ada dalam BI. Penggunaan penerjemahan ini menunjukkan bahwa anak usia prasekolah memiliki kemampuan untuk menggunakan strategi belajar yang dikategorikan sebagai strategi interlingual.

Kepribadian anak memberikan pengaruh terhadap penggunaan strategi belajar, khususnya kepribadian anak yang bersifat terbuka. Dengan kepribadian anak yang bersifat terbuka anak-anak cenderung tidak takut untuk melakukan kesalahan dan tidak malu untuk bertanya apabila meng-alami kesulitankesulitan. Dengan kepribadian terbuka ini pembelajar cenderung belajar lebih baik dalam hal keterampilan komunikasi interpersonal. Aspek kepribadian lain yang mempengaruhi penggunaan strategi belajar anak usia prasekolah adalah adanya keyakinan anak akan fungsi bahasa. Bagi anak usia prasekolah keyakinan tersebut telah ada dalam dirinya sejalan dengan kebutuhannya untuk berinteraksi dengan orang lain. Untuk memenuhi kebutuhan tersebut anak melakukan praktik berkomunikasi secara alami dengan berbagai mitra tutur di lingkungan masyarakat tutur pengguna bahasa target yang dipelajarinya. Hal ini tercermin pada strategi permintaan klarifikasi dan pertanyaan responsitimbal balik yang digunakan secara fungsional dalam praktik komunikasi.

Peran faktor intensitas masukan dan interaksi dalam pemerolehan kompetensi pragmatik anak usia prasekolah tampak pada penggunaan semua tipe dan variasi tipe strategi belajar. Beberapa strategi belajar baik peniruan tuturan, pengulangan tuturan, penggunaan pola tuturan, penerjemahan, permintaan klarifikasi, maupun pertanyaan responsi-timbal balik yang digunakan anak usia prasekolah dipengaruhi oleh masukan dan interaksi dari lingkungan bahasanya. Hanya saja tingkat keterpengaruhan faktor masukan dan interaksi pada penggunaan masing-masing strategi belajar tersebut tidak sama.

Sebagai contoh, peniruan tuturan dilakukan anak dalam dua cara, yaitu peniruan tuturan karena kesulitan penuturan dan peniruan tuturan karena kesalahan penuturan. Bentuk-bentuk tuturan yang ditirukan anak adalah tuturan orang dewasa atau tuturan orangorang di sekitarnya. Peniruan tuturan karena kesulitan penuturan dilakukan setelah anak mendapat masukan bentuk-bentuk tuturan yang belum diketahuinya, sedangkan peniruan tuturan karena kesalahan penuturan dilakukan setelah anak mendapat masukan berupa koreksi terhadap bentuk-bentuk tuturan yang tidak tepat penggunaannya. Semua perilaku anak dalam melakukan peniruan tuturan tersebut terjadi dalam interaksi yang terjadi secara alami. Dalam proses interaksi tersebut anak dapat melakukan berbagai hal, termasuk peniruan tuturan, untuk meningkatkan kompetensi pragmatiknya. Pragmatik merupakan kajian penggunaan bahasa dalam interaksi antara penutur dan mitra tuturnya.

Pengulangan tuturan dilakukan anak terhadap bentuk-bentuk tuturan yang belum dikuasai anak. Tipe strategi ini digunakan dalam tiga variasi, yaitu pengulangan tuturan sendiri, pengulangan tuturan orang dewasa, dan pengulangan tuturan teman sebaya. Pengulangan tuturan tersebut menunjukkan bahwa anak usia prasekolah telah menerima masukan bahasa dari lingkungannya dan dapat 
mempraktikannya dalam interaksi sesuai dengan konteks penggunaannya.

Penggunaan pola tuturan yang banyak dimanfaatkan anak usia prasekolah adalah pola tuturan keseharian. Pola tuturan ini lazim digunakan dalam komunikasi sehari-hari. Hal ini menunjukkan bahwa lingkungan bahasa anak memiliki peranan penting dalam penggunaan tipe strategi ini. Sejak awal pemerolehan bahasanya, anak dapat menggunakan pola tuturan keseharian yang sering dituturkan oleh orang-orang di sekitarnya. Dengan menggunakan bentukbentuk tuturan terpola sejak dini, anak dapat mengendapkan perolehan bahasanya sehingga dapat menguasainya dengan baik. Pemajanan bentuk pola tuturan keseharian ini merupakan langkah yang tepat agar anak dapat dengan mudah menerima pajanan tuturan tersebut dan langsung dapat mempraktikkannya dalam komunikasi. Hal ini membuktikan bahwa faktor masukan dan interaksi mendukung proses pemerolehan kompetensi pragmatik anak.

Penggunaan strategi belajar anak usia prasekolah berfungsi untuk menguasai bentukbentuk tuturan untuk menyatakan berbagai maksud kepada mitra tuturnya, yaitu bentukbentuk tuturan untuk (1) menyatakan fakta, (2) menyatakan pertanyaan, (3) menyatakan permintaan, (3) menyatakan nasihat, (4) menyatakan terima kasih, (5) menyatakan salam, (6) menyatakan perintah, (7) menyatakan permohonan, (8) menyatakan pendapat, dan (9) menyatakan simpulan. Fungsi penggunaan strategi belajar pada anak usia prasekolah tersebut pada tiap jenjang usia anak prasekolah berbeda-beda.

Perbedaan fungsi penggunaan strategi belajar pada tiap jenjang usia anak ini menandai adanya pengaruh perbedaan kematangan psikologis dan sosial budaya anak. Temuan penelitian ini membuktikan adanya keterkaitan antara proses pemerolehan bahasa sebagai gejala psikologis dan sebagai gejala sosial budaya, khususnya dalam pemerolehan kompetensi pragmatik. Sebagai gelaja psikologis, dalam proses pemerolehan kompetensi pragmatik anak diperlukan kematangan aspek mental untuk memetakan dan merepresentasikan kompetensi pragmatiknya dalam bentuk penggunaan tuturan yang sesuai dengan konteks pemakaiannya. Sebagai gejala sosial budaya, dalam pemerolehan kompetensi pragmatik anak mempelajari prinsip-prinsip penggunaan bentuk-bentuk tuturan yang sesuai dengan norma sosial budaya sehingga dapat menghasilkan tuturan yang berterima pada masyarakat tuturnya. Hal ini menandai adanya karakteristik pemerolehan kompetensi pragmatik sebagai proses perkembangan sosial budaya, yakni perkembangan seperangkat pengetahuan yang diperlukan untuk mencapai kebutuhan antarpersonal dengan menggunakan media bahasa.

Karakteristik fungsi penggunaan strategi belajar anak usia prasekolah tersebut berimplikasi tugas yang perlu diperhatikan oleh praktisi pendidikan. Para praktisi pendidikan anak usia prasekolah perlu memperhatikan secara khusus perkembangan dan kematangan kognisi anak agar dapat memperkenalkan bentuk-bentuk tuturan dan penggunaannya secara tepat kepada anak-anak untuk mengembangkan kompetensi pragmatiknya. Beberapa hal yang dapat dilakukan para praktisi pendidikan anak usia prasekolah adalah melakukan (1) penciptaan lingkungan belajar yang kondusif, (2) pemberian pajanan yang tepat, dan (3) pemberian kesempatan praktik berkomunikasi kepada anak. Penciptaan lingkungan belajar yang kondusif dapat diberikan dalam bentuk pemberian pajanan dan kesempatan praktik berkomunikasi yang sesuai dengan kebutuhan anak. Pemberian pajanan bentuk-bentuk tuturan yang kaya dan bervariasi sesuai dengan perkembangan kognisi anak ini diperlukan untuk mendukung kemampuan anak dalam menguasai bentuk-bentuk tuturan yang digunakan untuk menyatakan maksud sesuai dengan konteks penggunaannya. Pemberian kesempatan praktik berkomunikasi diperlukan anak sebagai sarana untuk memaksimalkan perkembangan kompetensi pragmatik anak melalui proses berinteraksi secara alami. 


\section{PENUTUP}

\section{Simpulan}

Konstruksi kreatif pemerolehan kompetensi pragmatik anak usia prasekolah tampak pada strategi belajar yang digunakan anak untuk menguasai bentuk-bentuk tuturan untuk menyatakan maksud kepada mitra tutur sesuai dengan konteks penggunaannya. Strategi pemerolehan tersebut ditunjukkan dengan caracara yang digunakan anak untuk memperoleh bentuk-bentuk tuturan tertentu untuk menyatakan maksud kepada mitra tuturnya.

Strategi belajar dalam pemerolehan kompetensi pragmatik anak usia prasekolah digunakan dalam dua kategori, yaitu strategi kognitif dan strategi sosial. Strategi kognitif digunakan dalam beberapa tipe, yaitu peniruan tuturan, pengulangan tuturan, dan perbaikan tuturan. Beberapa tipe strategi tersebut digunakan anak karena mereka belum menguasai bentuk-bentuk tuturan yang tepat untuk menyatakan maksud yang dibutuhkan dalam komunikasi. Berbagai strategi tersebut berfungsi untuk menguasai bentuk-bentuk tuturan yang baru diperkenalkan kepadanya, mencapai otomatisasi penggunaan bentuk-bentuk tuturan yang hendak dikuasainya, membantu membangun kepercayaan diri, dan meningkatkan pemahaman dan pemroduksian tuturan dalam BI, dan menghasilkan pesan dalam BI berdasarkan bentuk yang telah dikuasainya dalam BJ.

Strategi sosial digunakan anak dalam dua tipe, yaitu permintaan klarifikasi dan pertanyaan responsi-timbal balik. Permintaan klarifikasi dilakukan anak dalam bentuk permintaan penuturan kembali dan penjelasan maksud. Permintaan penuturan kembali berfungsi untuk memahami dan mengecek atau memastikan bahwa ia telah memahami bentuk tuturan tertentu dengan baik. Adapun permintaan penjelasan maksud dilakukan karena anak menyadari adanya kesalahan pada tuturannya dan ingin mendapat koreksi berupa penjelasan maksud dari mitra tuturnya. Cara ini berfungsi untuk memperoleh pembenaran secara langsung terhadap kesalahan yang telah dilakukannya sehingga anak dapat menggunakan bentuk tuturan yang benar pada kesempatan yang lain. Strategi pertanyaan responsi-timbal balik dilakukan karena anak bermaksud bekerjasama dengan mitra tutur dalam bentuk aktivitas bertanya-jawab. Pertanyaan responsi-timbal balik ini hanya digunakan anak usia prasekolah pada usia 5 tahun. Hal ini menandai bahwa pada usia 5 tahun terjadi perkembangan kemampuan anak dalam memanfaatkan strategi sosial dalam proses pemerolehan kompetensi pragmatiknya. Penggunaan berbagai strategi sosial tersebut merefleksikan adanya usaha-usaha yang dilakukan anak untuk mengatasi problem komunikasi secara alamiah sesuai dengan kebutuhan komunikasi anak dalam proses berinteraksi.

\section{Saran}

Berdasarkan temuan-temuan penelitian ini, berikut ini dikemukakan saran-saran kepada praktisi pendidikan dan peneliti berikutnya sebagai berikut.

Guru di Taman Bermain atau Taman Kanak-kanak perlu mengenali perkembangan kognisi anak dan penggunaan bentuk-bentuk tuturan anak yang merepresentasikan kompetensi pragmatiknya. Dengan cara ini guru dapat memberikan pajanan bentuk-bentuk tuturan yang kaya dan bervariasi sesuai dengan perkembangan kognisi anak sehingga dapat mendukung kemampuan anak untuk menguasai bentuk-bentuk tuturan yang digunakan untuk menyatakan maksud sesuai dengan konteks penggunaannya.

Guru perlu memahami bahwa penguasaan kompetensi pragmatik anak bersumber pada pengalaman dan kesan yang diperoleh anak terhadap kondisi, tingkah laku, dan fenomena yang ada di sekitarnya yang dapat diamati secara konkret oleh anak. Pemahaman itu dapat memaksimalkan perannya untuk menciptakan lingkungan belajar yang kondusif bagi perkembangan kompetensi pragmatik anak. Hal ini dapat dilakukan dengan cara melakukan penyesuaian-penyesuaian dalam rencara pembelajaran, memperhatikan kondisi siswa, fasilitas, media belajar bahasa, serta memaksimalkan pemberian kesempatan bagi 
anak untuk praktik berkomunikasi.

Dalam penelitian ini dikaji tentang strategi pemerolehan kompetensi pragmatik dengan menggunakan rancangan bujur (longitudinal) pada anak usia prasekolah pada usia 2, 3, 4, dan 5 tahun. Untuk mendapatkan hasil penelitian yang lebih komprehensif direkomendasikan pada peneliti berikutnya untuk mengkaji perkembangan strategi pemerolehan bahasa anak ini dengan menggunakan subjek pada usia 2 sampai dengan 5 tahun.

Dari hasil analisis data dalam penelitian ini ditemukan bahwa adanya pengaruh lingkungan dan budaya terhadap proses pemerolehan kompetensi pragmatik anak usia prasekolah. Pengaruh lingkungan dan budaya tersebut akan menarik apabila dikaji lebih lanjut dengan menggunakan model kajian etnografi komunikasi dan model akulturasi. Oleh karena itu, dari hasil penelitian ini direkomendasikan bagi peneliti berikutnya untuk mengkaji lebih lanjut dengan fokus kajian pada pengaruh lingkungan dan budaya terhadap pemerolehan kompetensi pragmatik anak usia prasekolah.

\section{DAFTAR PUSTAKA}

Burt, M. dan Heidi, D. 1991. Optimal Language Learning Environment. Dalam James, E. Alantis (ed). The Second Language Classroom. Oxford: Oxford University Press.

Clark, E. V. 2003. First language Acquisition. New York: Cambridge University Press.

Dardjowidjojo. S. 1988. PELLBA I (Pertemuan Linguistik Lembaga bahasa Admajaya). Jakarta: Arcan.

Dardjowidjojo. S. 2000. ECHA Kisah Pemerolehan Bahasa Anak Indonesia. Jakarta: Grasindo.

Dardjowidjojo. S. 2003. Psikolinguistik: Pengantar Pemahaman Bahasa Manusia. Jakarta: Yayasan Obor Indonesia.

Duranti, A. 2000. Linguistic Anthropology. Cambridge: Cambridge University Press.
Ellis, R. 1995. The Study of Second Language Acquisition. Oxford: Oxford University Press.

Foster, S. H. 1990. The Communicative Competence of Young Children. New York: Longman.

Goode, W.J. 2002. Sosiologi Keluarga. Jakarta: Bumi Aksara.

Harnis, R. M. 1991. Logical form and implicature. Dalam Davis, S. (ed.), Pragmatics: A Reader (hlm. 316-364). New York: Oxford University Press.

Holmes, J. 2001. An Introduction to Sociolinguistics. Edinburgh: Pearson Education Limited.

Levinson, S. C. 1992. Pragmatics. Cambridge: University Press.

Mbete, A. M. 2004. Linguistik Kebudayaan: Rintisan Konsep dan Beberapa Aspek Kajiannya. Dalam Bahasa dalam Perspektif Kebudayaan. Denpasar: Universitas Udayana.

Menno, S. dan M. Alwi. 1994. Antropologi Perkotaan. Jakarta: rajaGrafindo Persada.

Mey, Yacob L. 1993. Pragmatics an Introduction. Cambridge, Massachusetts: Blackwell Publisher Ltd.

Miles, M. B. dan A.M. Huberman. 1992. Analisis Data Kulaitatif. Terjemahan Tjetjep Rohendi Rohidi. Jakarta: UI Press.

Ninio, A. dan Catherine E. Snow. 1996. Pragmatic Development. USA: Wetsview Press, Inc.

Noremore R. C. dan Hoper, R. 1990. Children Learning Language. New York: Hoper \& Row Publisher.

Owens, Jr. R. E. 1996. Language Development: an Introduction. Fourth Edition. New York: Allyn and bacon.

Preston, D. 1989. Sociolinguistics and Language Acquisition. Oxford: Blackwell. 
Schiffrin, D. 1994. Approaches to Discourse Analysis. Cambridge: Blackwell Publisher.

Suparno. 1996. Penggunaan BJ dalam Keluarga Muda Etnis Jawa. Dalam Kartomihardjo, S. (Ed). Konggres Bahasa Jawa II 1996. Surabaya: Pemerintah Propinsi Daerah Tk. I Malang.

Wahab, A. 1991. Cerminan Budaya dalam Bahasa: Kasus Retorika Indonesia dalam Isu Linguistik, Pengajaran Bahasa dan Sastra. Surabaya: Airlangga Univerity Press.
Wahab, A. 2002. Kealpaan Terhadap Penghormatan dan Pemeliharaan Bahasa Daerah Pengemban Kebudayaan Nasional. Makalah disajikan dalam Konggres Linguistik Nasional (KLN) 2002. 